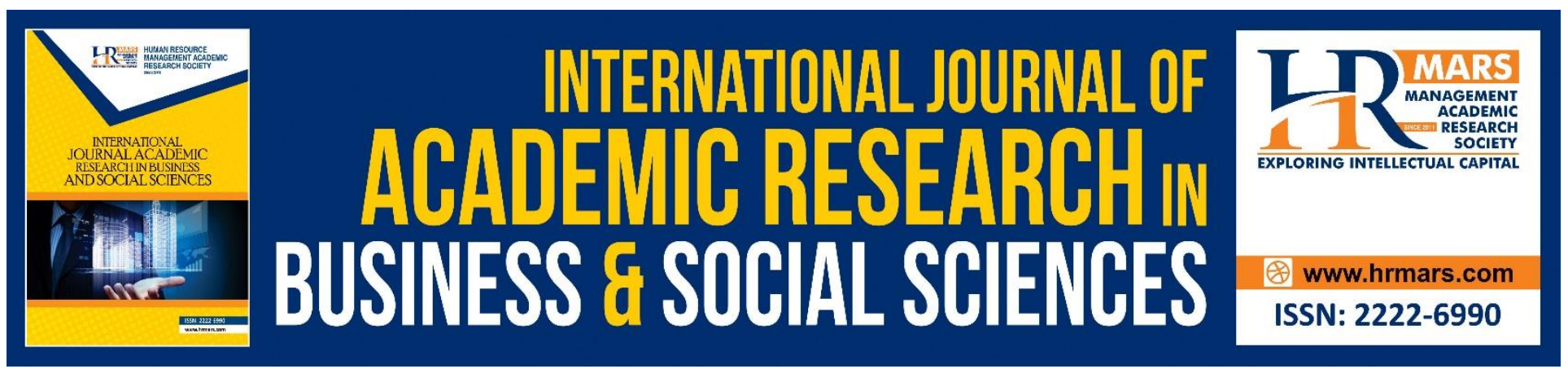

\title{
Strategic Management Practices Adopted by Public Benefit Organizations in Homa Bay County, Kenya
}

\author{
Moses Dayan Dekings \\ Leon Awiti \\ Ng'ong'a E. Aketch
}

To Link this Article: http://dx.doi.org/10.6007/IJARBSS/v9-i1/5474

DOI: $\quad 10.6007 /$ IJARBSS/v9-i1/5474

Received: 18 Dec 2018, Revised: 06 Jan 2019, Accepted: 21 Jan 2019

Published Online: 09 Feb 2019

In-Text Citation: (Dekings, Awiti, \& Aketch, 2019)

To Cite this Article: Dekings, M. D., Awiti, L., \& Aketch, N. E. (2019). Strategic Management Practices Adopted by Public Benefit Organizations in Homa Bay County, Kenya. International Journal of Academic Research in Business and Social Sciences, 9(1), 710-723.

Copyright: (C) 2019 The Author(s)

Published by Human Resource Management Academic Research Society (www.hrmars.com)

This article is published under the Creative Commons Attribution (CC BY 4.0) license. Anyone may reproduce, distribute, translate and create derivative works of this article (for both commercial and non-commercial purposes), subject to full attribution to the original publication and authors. The full terms of this license may be seen

at: http://creativecommons.org/licences/by/4.0/legalcode

Vol. 9, No. 1, 2019, Pg. 710 - 723

http://hrmars.com/index.php/pages/detail/IJARBSS

JOURNAL HOMEPAGE

Full Terms \& Conditions of access and use can be found at http://hrmars.com/index.php/pages/detail/publication-ethics 


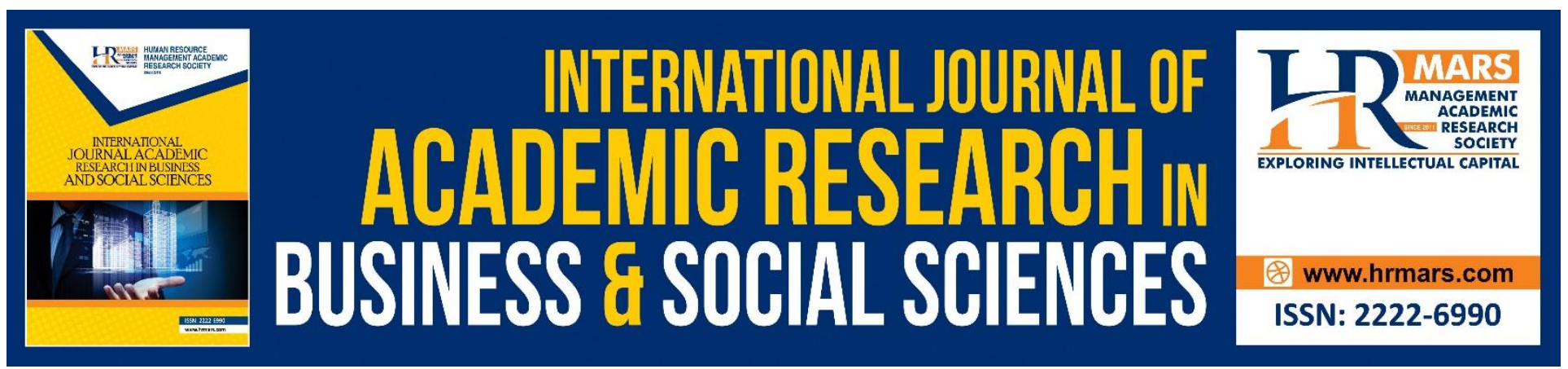

\title{
Strategic Management Practices Adopted by Public Benefit Organizations in Homa Bay County, Kenya
}

\author{
Moses Dayan Dekings \\ Graduate, Master of Business Administration, University of Nairobi,Kenya \\ Email: modekings2012@gmail.com \\ Leon Awiti, Ph.D. \\ Monitoring, Research, Evaluation and Learning Practitioner,Kenya \\ Email: awitileon @ gmail.com \\ Ng'ong'a E. Aketch, Ph.D \\ Email: aketchngonga@yahoo.com
}

\begin{abstract}
Public Benefit Organizations (PBOs) in Homa Bay County face various challenges that emanate from the environment they operate in. Strategic management practices are key to their survival as it enables them to understand the environment, define their goals and objectives and implement decisions better. The key to successfully prepare for the future is the ability of a firm to understand the environment and anticipate what industry trends and patterns may affect its current and future business and operation plans. The study sought to establish strategic management practices adopted by Public benefit organizations in Homa Bay County, Kenya. The study employed descriptive research design. The Population comprised approximately 497 public benefit organizations operating in Homa Bay County and are registered by the PBOs coordination Board. Sekaran's sample determination formula of 2013 was used to determine a sample size of 217 , simple random sampling technique was used to pick the sample from the population. Primary data was collected by use of semi-structured questionnaires. The target respondents were the senior managers and Coordinators heading PBOs in the Homa Bay County. The validity of the instruments was achieved by giving the questionnaires to experts for review. Test-retest was used to measure the reliability of the questionnaires. The correlation coefficient was computed using the Spearman rank order correlation and established to be $r=0.79$. The data was analyzed through descriptive statistics, frequency, percentage, mean and standard deviation, data analysis was aided by Statistical Package for Social Science (SPSS). The study found out that the majority of the PBOs in Homa Bay County have adopted some form of strategic management practices whether formal or informal. Nonetheless, strategic management seems not
\end{abstract}


to have been prioritized in majority of the organizations because a good number of PBOs do not have designated departments to coordinate strategic planning, execution and control. It was established that there were differential practices in so far as strategic management among PBOs is concerned, it was evident that situational analysis was least embraces among the strategic management practices. Strategy implementation was also weak, not at par with strategy formulation. Visioning and missioning were most popular among PBOs in Homa Bay County. The researcher concludes that PBOs have largely complied with all the five steps of strategic management but there is inconsistency in the way the practices are applied, and this could affect the effectiveness of strategic management processes. The study recommends that there is need to have designated personnel or department to manage the strategic management activities in the PBOs in Homa Bay County. Secondly, there is need to formalize the strategic management processes within the organizational setup so that they are not done haphazardly. Third, there is need for organizations to consistently apply all the strategic management practices, not to ignore some.

Keywords: Strategic management practices, Vision and mission, Situational analysis, Strategy formulation, Strategy implementation, Strategy evaluation.

\section{Background of the Study}

Heightened global competition, rapid environmental dynamics, and technological advances have compelled organizations to continuously change and adapt strategies, structures, practices, and processes to help them remain relevant and competitive. Organizations are sometimes forced to transform by abandoning stringent bureaucracies and adopting lenient designs in their management practices (Cummings \& Daellenback, 2009). Strategic management practices ensure long-term survival of organizations through efficiency and effectiveness. The overall aim is improving organizational performance in line with the rapidly changing socio-economic and political environments, which prompt organisations to adopt strategic management practices to achieve their strategic missions and objectives (Moldoveanu, 2009). Hence, organizations must embrace the right strategic management practices that they have designed for them to attain the desired level of performance.

Strategic management follows five phases, including constructing vision and mission statements, situational analysis, strategy formulation, strategy implementation, and strategy evaluation. It calls for all organizations to ensure that all of their efforts lead directly to the attainment of a set of objectives; and thus the achievement of the desired results (Porter, 2008). It focuses on outlining what strategic objectives are expected to achieve by emphasizing on continuous monitoring of projects against strategic goals and incorporating crucial lessons learned the time of designing management decisions and reporting on strategic attainment. Strategic management aims at the improvement of management efficiency, effectiveness, and accountability (Natarajan, Sridhar \& Abdul, 2008). As cited earlier, its main purpose encompasses improving effectiveness and efficiency by enhancing organizational learning and fulfilling organizational obligations. Organizations embrace strategic management because it results in favourable strategies such as total quality assurance in service, goal alignment, service delivery, and direct sharing because individual goals are closely linked or related to the overall organizational objectives (Adegbesan, 2009). Hence, aligning organisational 
performance measurements is related to its goals, coaching, development support, ongoing feedback, and recognition.

This study is anchored on theoretical foundations of Open System Theory, Institutional Theory, and Contingency theory. Open systems theory states that organizations are strongly influenced by environments in which they operate, including competitors that exert socio-economic, political, legal, and technological forces while providing resources for planning, implementing, and sustaining strategic change (Cummings \& Daellenback, 2009). Institutional theory focuses on interrelated rules and norms, their enforcement characteristics of formal rules and informal constraints, which govern different institutions (North, 1990). The Contingency theory posits that there is no best strategy to manage an organization. As Jones (2010) highlights, organization has to embrace appropriate strategic practices to attain fit between environment and structure.

The study will is based on Homa Bay County in the Nyanza province o Kenya. According to the PBO coordinating Board (2015), this County has 497 PBOs (475 local and 22 international PBOs). The PBOs implement various programs majorly in the following thematic areas of Health, Education, Livelihood, Governance and, Child Protection. The PBOs operating in Homa Bay County face several challenges in trying to deliver on their mandate. The competition for development funds has become stiff, their relevance is also challenged by coming of the County Governments that now demand more accountability, and people have become more enlightened and are demanding accountability from them among others challenges, which call for effective and efficient ways of managing their affairs and this is where strategic management practices.

\section{Problem Statement}

Organizations continuously face drastically changing rules and regulations, expectations, and competition for resource allocation. In this light, they must consistently embrace strategic management practices to be more effective and efficient for them to compete fairly. Public Benefit Organisations (PBOs) have to be transparent and hold to account so that they can continuously receive funds for development projects. Inadequate stakeholders' participation in the strategic management process is a key concern that is likely to compromise the popularity of strategies and organisational success.

Most PBOs in Kenya face the challenge of a lack formalised strategic management process and thus most of their activities are done haphazardly. Activities are executed because of compliance requirements as opposed to meeting the felt needs of the intended beneficiaries. This implies that they fail to achieve their strategic objectives. This study therefore intends to establish strategic management practices adopted by Public benefit organizations in Homa Bay County, Kenya.

\section{Purpose of the study}

The aim of this study was to determine the strategic management practices adopted by Public Benefit Organizations in Homa Bay County, Kenya

The study will focus on the five strategic management steps: Crafting of vision and mission, Situational analysis, Strategy formulation, Strategy implementation and Strategy evaluation. 


\section{Literature Review}

\section{Visioning and Missioning}

Stewart, May, and Kalia (2009) posit that organisational mission statement is essentially its statement of purpose. Haase and Franco (2011) confirm this that a mission statement provides insight into what organizational leaders view as the primary purpose for involvement in a project. The mission statement provides the answer to the question: why an organization exists. It provides the organization purpose and meaning and speaks to why people want to work for one's organisation. It begins to answer the question, what is strategic management and planning. Johnson and Scholes (2010) define vision as an inspirational description of what a project intends to achieve or accomplish in the mid-term or long-term future. It is meant to serve as a clear guide for choosing current and future courses of action for successful project implementation. While a mission is a statement of what is, a vision is a statement of what or how organisation intends the project activities to be.

\section{Environmental Scanning Practices}

Kameri-Mbote (2009) on strategic planning and implementation of public involvement in environmental decision, defines environmental scanning as monitoring, evaluating, and disseminating of information from the external and internal environment to key people involved in a project. It is a process of collecting, analyzing, and disseminating information for tactical or strategic purposes. The processes therefore process entails gathering subjective and factual data on the environment the organization is intending to implement its activities, processing into information and utilizing the same. A study by Kathama (2012) found that intelligence-rationality factor, which comprises environmental scanning, controls, communication, adaptiveness, analysis, integration, multiplexity, and industry experience, was by far the most important factor in separating the successful companies from the unsuccessful, accounting for more than half of the observed variance.

\section{Strategy Formulation Practices}

According to Jean Diana, and Avan (2011), strategy formulation can be defined as the process of choosing the most appropriate course of action for the realization of project goals and objectives and thereby achieving the vision. The process of strategic planning processes constitutes a number of phases. Although the steps do not follow a rigid chronological order, they are very rational and can be easily followed in this order. In the strategy formulation process, leaders set the objectives then analyze the environment both internal and external. Then fix the targets to be achieved, sets measures for project performance evaluation and finally select or formulate the proper strategy (Wholey, Hatry, \& Newcomer, 2010). Strategy formulation focuses mainly on planning for future whereas strategy implementation is a process of conversion in which planned strategies are changed into real actions to realise goals and objectives.

\section{Strategy Implementation Practices}

Yusuf and Saffu (2009) define strategy implementation as the translation of chosen strategy into a strategic planning action to achieve strategic goals and objectives. Strategy implementation is also referred to as the manner in which projects should utilize and amalgamate organizational structure, control systems, and culture to follow strategies that lead to their better performance (Azhar, 2009). 
Organizational structure allocates special value developing tasks and roles to the stakeholders and defines how these tasks and roles can be linked to maximize project efficiency, quality, and beneficiaries' satisfaction. Eskerod and Riis (2009) argue that implementation is a key component of the strategic planning process. It has been defined as the process that turns strategies and plans into actions to accomplish organisational objectives. It addresses who, where, when, and how to carry out organisational activities successfully to achieve better project results. Implementing a project strategic change is a double-edged sword because it simultaneously generates expected performance gain and unexpected project performance failures.

\section{Strategy Evaluation Practices}

Jaeger and Adair (2013) define strategy evaluation and control as the process of determining the effectiveness of a given strategy in achieving the project objectives and taking corrective actions whenever there is need. Strategy Evaluation is as significant as strategy formulation because it sheds light on the efficiency and effectiveness of the comprehensive plans in achieving the desired project results. The managers can also assess the appropriateness of the current strategy. Dess (2012) emphasises the importance of monitoring projects at frequent intervals and on a timely basis. Monitoring and control are usually viewed as a single activity because they are both project management functions, sequential and closely interlinked.

\section{Study Methodology}

A cross sectional descriptive research design was adopted in this study. The target population for this study was all the 497 Public Benefit Organizations operating in Homa Bay County and are registered by PBO Coordination board as per PBOs Co-ordination Act, 1990. Sekaran's sample determination formula of 2013 was used to determine a sample size of 217, simple random sampling technique was used to pick the sample from the population. Primary data was collected by use of semi-structured questionnaires dropped to the respondents and picked after three days. The target respondents were the senior managers and Coordinators heading PBOs in the Homa Bay County. The validity of the instruments was achieved by giving the questionnaires to experts for review. Test-retest was used to measure the reliability of the questionnaires. The correlation coefficient was computed using the Spearman rank order correlation and established to be $r=0.79$. The data was analyzed through descriptive statistics, frequency, percentage, mean and standard deviation, data analysis was aided by Statistical Package for Social Science (SPSS). The Likert scale items were analysed and interpreted on a scale of 1 to 5 where $1=$ not at all, $2=$ =a little extent, $3=$ moderately extent, $4=$ great extent, $5=$ very great extent. Data analysed were obtained from 168 (77.41\%) out of the targeted 217 PBOs hence becoming an effective sample size. 
INTERNATIONAL JOURNAL OF ACADEMIC RESEARCH IN BUSINESS AND SOCIAL SCIENCES

Vol. 9, No. 1, Jan, 2019, E-ISSN: 2222-6990 (C) 2019 HRMARS

Study Findings

Organizational Profiles

Table 1: Organization profiles

\begin{tabular}{|c|c|c|}
\hline Aspects of organization profile & Response category & $f(\%), n=168$ \\
\hline \multirow[t]{2}{*}{ Scope of the PBO } & International PBO & $25(14.9 \%)$ \\
\hline & Local PBO & $143(85.1 \%)$ \\
\hline Number of years PBO has been operating in & $0-5$ & $57(33.9 \%)$ \\
\hline \multirow[t]{3}{*}{ Homa Bay County } & $6-10$ & $51(30.4 \%)$ \\
\hline & $11-15$ & $34(20.2 \%)$ \\
\hline & $16-20$ & $26(15.5 \%)$ \\
\hline \multirow[t]{2}{*}{ Presence of strategic planning department } & Yes & $75(44.6 \%)$ \\
\hline & No & $93(55.4 \%)$ \\
\hline \multirow[t]{4}{*}{ Number of employees } & $0-10$ & $85(50.6 \%)$ \\
\hline & $11-20$ & $50(29.8 \%)$ \\
\hline & $21-50$ & $17(10.1 \%)$ \\
\hline & Over 50 & $16(9.5 \%)$ \\
\hline \multirow[t]{4}{*}{ Annual Budget } & Less than 20 million & $86(51.2 \%)$ \\
\hline & 21-50 million & $33(19.6 \%)$ \\
\hline & $61-100$ million & $33(19.6 \%)$ \\
\hline & Over 100 million & $16(9.5 \%)$ \\
\hline \multirow[t]{4}{*}{ Caliber of management staff } & Not technical & $8(4.8 \%)$ \\
\hline & $\begin{array}{l}\text { Technical specialist } \\
\text { without mgmt. training }\end{array}$ & $18(10.7 \%)$ \\
\hline & $\begin{array}{l}\text { Technical specialist with } \\
\text { mgmt. training }\end{array}$ & $126(75.0 \%)$ \\
\hline & Others (please specify) & $16(9.5 \%)$ \\
\hline \multirow[t]{7}{*}{ Involvement in strategic planning } & Yes & $168(100 \%)$ \\
\hline & No & $0(0 \%)$ \\
\hline & 1996-2000 & $9(5.4 \%)$ \\
\hline & 2001-2005 & $32(19.0 \%)$ \\
\hline & 2006-2010 & $52(31.0 \%)$ \\
\hline & 2011-2015 & $51(30.4 \%)$ \\
\hline & Could not remember & $24(14.3 \%)$ \\
\hline
\end{tabular}

Majority of the PBOs were local at 143(85.1\%) while the international PBOs stood at 25(14.9\%). This meant that Homa Bay County is dominated by the local PBOs who understood the developmental issues better, translating into home-grown strategies in addressing them. Majority of respondents said their organizations had been operating in Homa Bay County for 0-5 years at $57(33.9 \%)$, minority of the respondents said their organizations had operated for $16-20$ years at $26(15.5 \%)$. This gave balanced responses in relation to strategic management practices and experienced with a reasonable number of PBO in each period category. Majority of the respondents said that their organization didn't have a strategy management department at 93(55.4\%). This meant that strategic management processes are not prioritized and given the much-needed focus in most PBOs in Homa Bay County. 
INTERNATIONAL JOURNAL OF ACADEMIC RESEARCH IN BUSINESS AND SOCIAL SCIENCES

Vol. 9, No. 1, Jan, 2019, E-ISSN: 2222-6990 @ 2019 HRMARS

The processes are likely to be handled by personnel who have other responsibilities and may not give much attention to streamlining strategic practices in their respective organizations.

Majority of the respondents said that their organization had between 0-10 employees at 85(50.6\%) ,the minority said that their organization had over 50 employees at 16(9.5\%).Majority of the respondents said their organizations had an annual budget of less than 20 million. The minority of the respondents stated that their organization had a budget of over 100 million at 16(9.5\%). A good number of $\mathrm{PBOs}$ had reasonable budgets that would enable adequate implementation of strategic focus and goals. Majority of the respondents confirmed that their senior staff had technical skills and management-training at $126(75 \%)$. The Minority of the respondents said that their calibre of staff had no technical skills and management training at $8(4.8 \%)$. This meant that majority of the organizations had the requisite skills in staff to enable proper strategic planning and management practices.

All the respondents noted that their organizations are involved in the strategic management practices within their organization at $168(100 \%)$. This meant that all the organizations were engaged in some strategic management practices, that is formal or informal, organized or haphazard. Majority of the respondents said that their organizations developed their first strategic plan between 2006-2010 at $52(31 \%)$. The minority of respondents said their organization developed their strategic plan between $1996-2000$ at $9(5.4 \%)$.

Table 2: Strategic focus area

\begin{tabular}{lllllll} 
& Health & HIV/AIDS & Education & Governance & Livelihood & Advocacy \\
\cline { 2 - 7 } Yes & $100(59.5 \%)$ & $83(49.4 \%)$ & $85(50.5 \%)$ & $41(24.4 \%)$ & $108(64.3 \%)$ & $82(48.8 \%)$ \\
No & $68(40.5 \%)$ & $\mathbf{8 5}(50.6 \%$ & $83(49.4 \%)$ & $127(75.6 \%)$ & $60(35.7 \%)$ & $86(51.2 \%)$ \\
Total & $\mathbf{1 6 8 ( 1 0 0 \% )}$ & $\mathbf{1 6 8 ( 1 0 0 \% )}$ & $\mathbf{1 6 8 ( 1 0 0 \% )}$ & $\mathbf{1 6 8 ( 1 0 0 \% )}$ & $\mathbf{1 6 8 ( 1 0 0 \% )}$ & $\mathbf{1 6 8 ( 1 0 0 \% )}$ \\
\hline
\end{tabular}

Most of the organizations gave prominence in their strategic focus to Health, Education and Livelihood at 100(59.5\%),85 (50.6\%) and 108(64.3\%) respectively, while Governance was the least focused area at $41(24.4 \%)$. This was confirming the fact that Homa Bay County is one of the worst performing Counties in health indicators in the Country and therefore many PBOs were putting resources in this area to try to address the health challenges.

Organizational visioning and missioning practices

Table 3: Presence, Strategies and Frequency for vision and mission

\begin{tabular}{|c|c|c|}
\hline $\begin{array}{l}\text { Presence, Strategies and Frequency for vision and } \\
\text { mission }\end{array}$ & Response category & $f(\%), n=168$ \\
\hline \multirow[t]{2}{*}{ Presence of a vision and mission statement } & Yes & $168(100 \%)$ \\
\hline & No & $0(0 \%)$ \\
\hline \multirow[t]{2}{*}{ Strategies for developing vision and mission statements } & Benchmarking & $69(41.1 \%)$ \\
\hline & Consensus & $99(58.9 \%)$ \\
\hline \multirow[t]{3}{*}{ Frequency of reviewing vision and mission } & Every 5 years & $91(54.2 \%)$ \\
\hline & Annually & $51(30.4 \%)$ \\
\hline & Others & $26(15.5 \%)$ \\
\hline
\end{tabular}


All the respondents confirmed that their organization had a vision and mission statement at $168(100 \%)$. This is an important part of strategy because mission statement facilitates the communication of the organization's direction and purpose, provides a control mechanism over the behaviour of employees, and assists the organization to create a balance between competing interests of various stakeholders as well as focused resource allocation for improved performance of organizational interventions.

Majority of the respondents said that their organizations mission and vision are developed through consensus at 99(58.9\%).The minority of the respondents said that they develop their mission and vision through benchmarking at 69(41.1\%). This meant that vision and mission statements were largely home-grown and in line with the felt needs and aspirations.

It was popular among the respondents to state that they reviewed their vision and mission statement after every 5 years at 91(54.2\%).The respondents that said that they reviewed vision and mission statement annually stood at $51(30.4 \%)$. The least number of respondents said that they reviewed their vision and mission statement after other period other than the first two options at 26(15.5\%), in this category some respondents mentioned that they modified after every three years. This meant that the organizations were probably true to the emerging developmental issues necessitating frequent reviews of the vision and mission.

\section{Situational Analysis Practices}

Table 4: Extent of conducting situational analysis

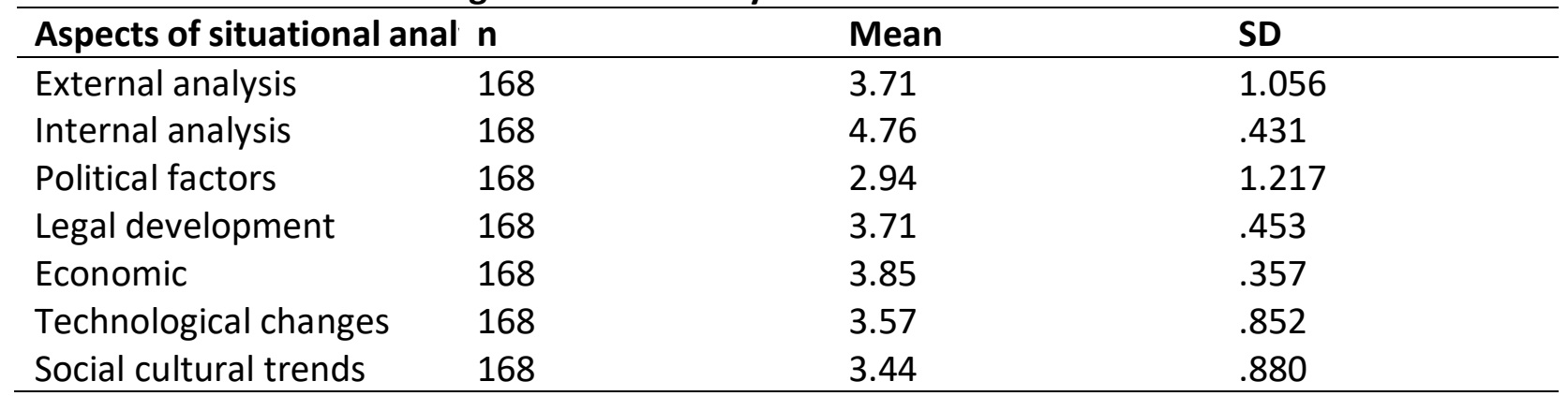

Majority of the respondents said they used external analysis in the strategic management process to a great extent in their organization (Mean=3.71, SD=1.056). Majority of the respondents also agreed they involved the political factors in the strategy formulation process within the organization to a moderate extent (Mean=2.94, SD=1.217). It was popular among the respondents who agreed that they involved the technological changes in their strategy formulation process in their organization (Mean=3.57, SD=0.852). Ultimately majority of the respondents said that they involved socio cultural trends in their strategy formulation process in their organization to a moderate extent (Mean=3.44.SD=0.880). 
INTERNATIONAL JOURNAL OF ACADEMIC RESEARCH IN BUSINESS AND SOCIAL SCIENCES

Vol. 9, No. 1, Jan, 2019, E-ISSN: 2222-6990 (C) 2019 HRMARS

Strategy Formulation Practices

Table 5: Extent of conducting strategy formulation

\begin{tabular}{llll}
\hline Strategy formulation & $\mathbf{n}$ & Mean & SD \\
\hline & & & \\
Appraising strategic risks & 168 & 4.10 & .949 \\
Establishing strategic direction & 168 & 4.35 & .719 \\
Strategy formulation & 168 & 4.40 & .798 \\
\hline
\end{tabular}

The respondents agreed that their organization applied evaluation of risks in the strategic management process to a great extent (Mean=4.10, SD=0.949). Majority of the respondents said that their organization applied the establishment of strategic direction in the strategic management process to a great extent (Mean=4.35, SD=0.719). Most of the respondents concurred that their organization applied strategy formulation in the strategic management process to a great extent (Mean=4.40, SD=0.798).

All the respondents confirmed that their organizations had set objectives for the organization at $168(100 \%)$. This meant that the organizations operations were well guided and focused towards some developmental goals. Further, majority of the respondents said that all their employees were aware of their objectives at 160(95.2\%).

\section{Strategy Implementation Practices}

Table 6: Extent of strategy implementation

\begin{tabular}{llll}
\hline Strategy implementation & $\mathbf{n}$ & Mean & SD \\
\hline Strategic finding & 168 & 4.27 & .886 \\
Strategy implementation & 168 & 4.57 & .586 \\
\hline
\end{tabular}

Majority of the respondents agreed that their organization applied strategic finding in the strategic management process to a great extent (Mean=4.27, SD=0.886). Majority of the respondents said their organization apply the strategic implementation in the strategic management process to a very great extent (Mean=4.57, SD=0.586).

Majority of the respondents said that their organization committed strategies to the organization internally and to the external relevant bodies at 141(83.9\%). A number of respondents also said that their organization committed their strategies to the external relevant bodies at $18(10.7 \%)$. The minority number of respondents said that their organization committed their strategies internally in the organization at $9(5.4 \%)$.

Majority of the respondents said that their organization communicated their strategic plans through circulars and memos at $152(90.5 \%)$. A minority of the respondents said that their organization communicated their strategic plans by word of mouth at $25(14.9 \%)$.

Strategy Evaluation and Control Practices

Table 7: Strategy Evaluation and Control

\begin{tabular}{llll}
\hline & $\mathbf{n}$ & Mean & SD \\
\hline Strategy monitoring during implementation & 168 & 4.57 & .585 \\
Evaluation of strategic options & 168 & 4.31 & .709 \\
\hline
\end{tabular}


Most of the respondents said that their organization applied the evaluation of strategic options in strategic management process to a great extent (Mean=4.31, SD=0.709). Strategy monitoring during implementation was carried out to a very large extent by majority of the organizations (Mean=4.57, $\mathrm{SD}=0.586)$.

\section{Summary of Differential Practice of Strategic Management}

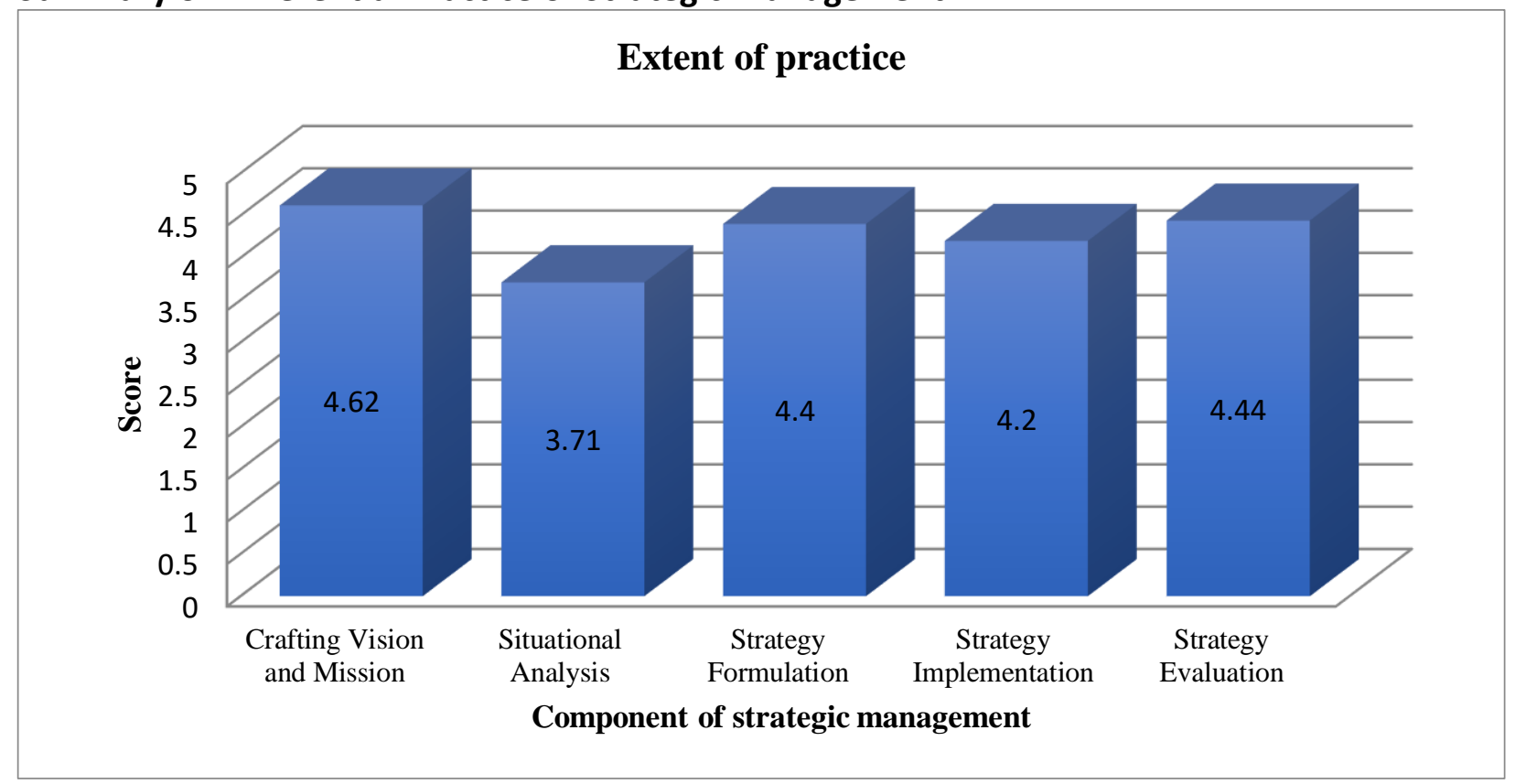

Figure 1: Differential Practices in Strategic Management

It was noted that there were differential practices in so far as strategic management are concerned, it was evident that most organizations do not conduct situational analysis. Strategy implementation was also weak, not at par with strategy formulation.

\section{Discussion of Findings}

This study revealed that strategic management was a very common practice among PBOs in Homa Bay County. This meant that the organizations followed through the five steps of strategic planning whether formally or informally as outlined by Thompson and Strickler (1999): Crafting organizational mission and vision, Environmental scanning, Strategy formulation, Strategy implementation and, Strategy evaluation and control. It was established that all the PBOs developed mission and vision and most of them were revised after every 5 years. It is clear that the organizations took cognizance of David (1986) assertions that a mission statement is as enduring statement of purpose that distinguishes one organization from the other and similar organization and those of Thomas \& stickler (1999) that developing the organization's vision reflects the core values that the organization would like to communicate to all its stake holders.

The finding of this study converges with those of Kotler (1999) in underscoring situational analysis as a step in strategic management. Majority of the PBOs carried out situational analysis using PESTEL and SWOT analysis which Kotler says is sometime referred to as environmental analysis and notes 
that this step is important is important in enabling the organization to know what factors in the internal external environment is likely to impact on its work and on the other hand how the organizational activities are likely to impact on the operating environment.

This study corroborates the significance of strategy formulation in the strategic management process, the PBOs established strategic direction to a large extent and they did objective setting. This in convergence with Bordean et.al. (2009) assertions that strategy formulation consists of determining the organization's goals, and objectives and selecting or crafting an appropriate strategy. They also note that essentially, crafting the strategy can be thought of as a continuous effort to develop a set of directions, draft a blueprint or draw a road map. This study revealed that strategy implementation is carried out by majority of the organizations to a very great extent, and that they are funded to a great extent. This is in line with the assertions by Karachi (2000) and Kama (2008) that successful implementation requires that plan be linked to other systems of the organisations like budgets and other resources, they also both do agree that involvement of both management and employees give rise to successful implementation of strategies. Majority of the PBO in the study confirmed that the strategies were largely committed to both internal and to the external relevant bodies.

This study confirms that strategy evaluation and control is deemed a very important step in strategic management by the PBOs in Homa Bay County, most of the organizations carried it out to a very large extent. This is in line with the Wheelan and Hunger (2010) that strategy evaluation and control is the last step in the strategic planning practices, they that the step is important because it enables the organization to continuously monitor the actual performance of objectives and goals. It helps the organizations to use the information to take corrective action and resolve problems.

\section{Conclusions and Recommendations Conclusions}

It was concluded that majority of the PBOs in Homa Bay County have adopted some form of strategic planning and management practices, whether formal or informal.

It was inferred that strategic management practices were not prioritized in majority of the organizations since they did not have designated departments to coordinate strategic planning, implementation and control.

There were differential practices in so far as strategic management among PBOs is concerned, it was evident that situational analysis was least embraces among the strategic management practices. Strategy implementation was also weak, not at par with strategy formulation. Visioning and missioning were most popular among PBOs in Homa Bay County. This could affect the effectiveness of strategic management processes.

\section{Recommendations for Policy and Practice}

It is recommended that the PBOs need to adopt formal strategic planning practices and consistent application of the same.

There is need for the PBOs to have designated personnel or department to manage the strategic Management activities in the PBOs in Homa Bay County. 
There is need for the PBOs in Homa Bay County to consistently apply all the strategic management practices, not to ignore some. This will enhance the effectiveness of the strategic management process in terms of helping the organizations in realizing their strategic intentions.

\section{Limitations of the Study}

During data collection, some respondents were unwilling to give data on their business especially the financial statements and personnel data as they considered it confidential even after assuring them that it would be used for education only and not for any other purpose. Therefore some information may not be accurate. To address this, the respondents addressed this by assuring the respondents of confidentiality.

Due to pressure of time constraints some respondents may have rushed in responding to the questionnaires to allow time for other more pressing organization issues. This may have compromised the quality of the data. The researcher checked the questionnaires for completeness and consistency before picking them.

\section{Suggestion for Further Research}

The aim of the study was to determine the strategic management practices adopted by Public Benefit Organizations in Homa Bay county, Kenya. It would be interesting to investigate how these strategic management practices affects the performance of the PBOs in Homa Bay county as far as execution programs is concerned.

An investigation could also be done to find out why PBOs in Homa Bay County practice strategic management differentially, why some practices are favoured compared to the rest.

\section{References}

Adegbesan, J. (2009). On the Origins of Competitive Advantage: Strategic Factor Markets and Heterogeneous Resources Complementarity, Academy of Management Review, July 2009.

Azhar, K. (2009). Strategic Management and Business Policy 3rd ed. India, Tata McCrian-Hill Publishing.

Bordean, O., Borza A.,Rus, C. \& Mitra, C. (2009). An investigation on the strategy

formulation process within the Romanian companies.Cluj-Napoca, Risoprint Publishing House.

Cummings, S. \& Daellenback, U. (2009). A Guide to the Future of Strategy? The History of Long Range Planning. Long Range Planning, April 2009.

Dess, C. (2012). Strategic Management Formulation. India, McGraw Hill International Book Company.

Eskerod, P. \& Riis, E. (2009). Value Creation by Building an intera-organizational common frame of reference concerning project management. Project Management Journal, 40(3):6-

13.

Haase, H. \& Franco, M., (2011). Information sources for environmental scanning: do industry and firm size matter? Management Decision, 49(10): 1642-1657.

Jaeger, M. \& Adair,D. (2013). Organizational culture of construction project managers in GCC countries. Engineering, Construction and Architectural Management, 20(5): 461-473. 
INTERNATIONAL JOURNAL OF ACADEMIC RESEARCH IN BUSINESS AND SOCIAL SCIENCES

Vol. 9, No. 1, Jan, 2019, E-ISSN: 2222-6990 (C) 2019 HRMARS

Jean, E., Diana, P., \& Avan, W. (2011). Making Connections. Using a theory of change to develop planning and evaluation. London: Charities Evaluation Services.

Johnson, G, \& Scholes, K. (2010). Exploring Corporate Strategy. London: Prentice Hall Publishers. Jones, M. L. (2010). What do Managers do during Major Organizational Change? NSW: University of Wollongong.

Kameri-Mbote, P. (2009). Strategic planning and implementation of public involvement in environmental decision. Environmental Law Research Centre Working. Nairobi.

Kathama, L. (2012). Strategic planning practices and performance of state corporations in Kenya. Unpublished MBA thesis. Nairobi: University of Nairobi.

Kotler, J. (1999). What Leaders Real and Do. Boston: Harvard Business School Press.

Moldoveanu, M. (2009). Thinking Strategically About Thinking Strategically: The Computational Structure and Dynamics of Managerial Problem Selection and Formulation. Strategic Management Journal, July 2009.

Natarajan, V., Sridhar, P., \& Abdul, R. (2008). The Intellectual Structure of the Strategic Management Field: An Author Co-citation Analysis. Strategic Management Journal, 29 (3).

North, D. (1990). Institutions, Institutional Change and Economic Performance. Cambridge:Cambridge University Press.

Porter, M. E. (2008). The Five Competitive Forces That Shape Strategy. Harvard Business Review, January 2008.

Stewart, J., May, R., \& Kalia, A. (2009). Environmental perceptions and scanning in the United

States and India: convergence in entrepreneurial information seeking? Entrepreneurship: theory and practice, 32(1): 83-106.

Thompson, A. A. and Stickler, A..J. (1993).Strategic management , concept and cases. $7^{\text {th }}$ Edition. New York: Richard D, Irwin Inc

Wheelen, T. L., \& Hunger, J. D. (2010). Concepts in strategic management and business policy (12th ed.). Retrieved from The University of Phoenix eBook Collection.

Wholey, J., Hatry, H., \& Newcomer, K. (2010). Handbook of practical program evaluation ( 3rd Ed.). San Francisco: Jossey-Bass.

Yusuf, A., \& Saffu, K. (2009). Planning practices, strategy types and firm performance in the Arabian Gulf region. Education, Business and Society: Contemporary Middle Eastern Issues, 2(3): 203-217. 